\title{
THE ROLE OF EXTERNAL STAKEHOLDERS IN ENSURING THE QUALITY OF EDUCATIONAL SERVICES OF POLOTSK STATE UNIVERSITY
}

\author{
Nadzeya Bareika $^{1}$, Alena Barun $^{2}$, Natallia Dauhiala ${ }^{2}$, and Dzmitry Dauhiala ${ }^{1}$ \\ ${ }^{1}$ Polotsk State University, 211440 Novopolotsk, Belarus
}

\begin{abstract}
In modern conditions, the task of integrating science, education and innovation activities is of great importance. The need for highly qualified and proactive employees leads to the natural integration of the University and employers, who are the main external stakeholders and consumers of educational services. The article discusses the main forms of interaction between Polotsk State University and the main enterprises and organizations of the region. The main results of comprehensive monitoring of employers ' satisfaction with the quality of training specialists in the higher educational institution are presented. The assessment of consumer satisfaction with educational services in the framework of this monitoring was carried out on the basis of a competence campaign. This is primarily due to the fact that the quality of education is determined precisely by the competencies formed by the graduate, which allow applying the acquired knowledge, skills and abilities in solving specific professional tasks. The monitoring demonstrated a high level of development of a number of competencies, in particular the competence "ability to use information and communication technologies", which highlights the fact that the educational programs of compulsory and additional education implemented at Polotsk State University provide the knowledge and practical skills necessary for using the latest ICT in professional activities. Employers have also identified the scarce skills of graduates, namely "Ability to take decisive action in case of uncertainty", "Ability to anticipate a problem" and "Ability to use time effectively". Based on the self-assessment of graduates, during their studies at Polotsk State University they have to a large extent developed the competences required for successful work in today's economy. The success of Polotsk State University graduates is clear evidence of the high quality of their training.
\end{abstract}

\section{Introduction}

The implementation of strategies and programs for the development of educational institutions, including universities, involves active interaction with numerous organizations, groups and individuals [1]. At present, it is becoming obvious that in addition to the two traditional missions that the University carries out - educational and scientific-the third one plays a significant role, which is related to participation in the development of the region where it is located[2]. The analysis of University development programs has shown that the 
main focus of universities is to promote the socio-economic development of regions, primarily through training and strengthening the potential of University science. To analyze all the functions of the University, the main provisions of the theory of stakeholders can be applied, which is successfully used in the field of strategic management of commercial organizations. According to this theory, stakeholders (key actors) not only have some interest in the development of the organization, but also are a resource and even an engine of this development [3].

\section{Methods and materials}

There are many definitions of stakeholders (groups of influence), which most often refer to any group or individual that can influence the organization's activities [4]. Many Russian authors, such as A. I. Patrakhin, V. N. Strekalovsky and V. M. Savvinov, V. A. Nagornov and O. V. Perfileva, E. S. Popova and others consider it possible to implement the theory of stakeholders in the field of higher education and consider University management from the position of "stakeholder management" [5]. In this case, a stakeholder is a understood as a legal entity or individual who receives educational services or is interested in the results of educational activities at the University.

E. S. Popova identifies 6 main groups of stakeholders in relation to the University: regional authorities; secondary education institutions and other higher educational institutions located in the region; large industrial enterprises; small and medium-sized businesses; the labour market; civil society institutions[6].

$\mathrm{K}$. Yu. Burtseva, applying a process approach to the activities (educational and scientific) of universities, considers it appropriate to categorize stakeholders according to the blocks of the process: enrolment, graduation, management, resources. The stakeholder groups are divided as follows:

- at the level of enrolment: enrollees, students, schools and other suppliers of students;

- at the level of graduation: graduates, employers, state and society;

- at the level of management: the Ministry of Education;

- at the level of resources: academic staff, university management and staff, as well as rival higher educational institutions[7].

The most popular approach is to identify two groups of key stakeholders whose interests and requirements affect the functioning and development of universities.

Thus, V. M. Savvinov and V. N. Strekalovsky. categorizestakeholders into two groups: external and internal stakeholders. The first groupof external stakeholders includes:

- the state that implements the legal regulation of the University's activities and the main order for training specialists through the distribution of control figures for budget admission;

- regional and localgovernment authorities;

- employers (large industrial enterprises, small and medium-sized businesses, social institutions) interested in obtaining competent specialists;

- students, enrollees and their parents who are at the stage of choosing an educational institution;

- educational institutions of various types located in the region;

- various public organizations and associations that are not directly related to the education system (political parties, ethnic and other social groups, creative unions, scientific institutions, etc.), but which are interested in social partnership.

The second group is internal stakeholders. It includes:

- students at different levels of education (bachelor's, master's, postgraduate and doctoral) and their parents;

- research and academic staff, support staff, and administrative and managerial staff [1]. 


\section{Results}

The direct user of the finished product of the University's well-coordinated activities is an employer-stakeholder. Nowadays business contribution to the definition of the objectives of education, contents of educational programmes, as well as the overall direction of the University's activities has grown significantly[8]. Employers increasingly interact with educational institutions, participating both in the formation of the order on preparation of specialists of the required profile and qualification, and assessing the quality of the content and graduates [9].

Polotsk State University is a major educational, scientific, and cultural center of the Polotsk industrial region, which is based on oil refining and chemical production (JSC "Naftan"), power generation (Lukomlskaya SDPP, Novopolotsk CHPP), and construction production. These enterprises work closely with the University, expanding the organizational forms and content of the partnership. The main areas of cooperation between Polotsk State University and employers are:

The special requests for specialist training (contracts on employer-sponsored education). Such cooperation involves the conclusion of a contract between the University and the enterprise for which the specialist is trained. At the time of the enrollment campaign in 2020, 11 contracts on employer-sponsored education were signed with Polotsk State University for the training of pedagogical and law specialists. The big advantages of such interaction for universities is a clear definition of the requirements for graduates ' competencies on the part of the employer.

Selection of graduates for a specific enterprise. This form of cooperation involves the participation of employers primarily in the work of the State examination Board, in order to select the best graduates of the educational institution [10].

Providing places for work experience. An important content aspect of interaction between educational institutions and employers is the organization of industrial practice, providing a base for writing term papers and theses.

Employer's participation in the educational process. Such participation means the involvement of practitioners in educational activities, the creation of branches of departments, and the organization of internships for University academic staff at the enterprise. As of March 2020, there are 51 branches of departments of Polotsk State University.

One of the successful strategies for cooperation between the University and employers was the creation of the Novopolotsk Petrochemical cluster in 2017, at the initiative of PolotskState University, together with JSC "Naftan" and the NovopolotskCity Executive Committee [11]. As well as participation of representatives from the main enterprises where the university graduates work (Novopolotsk City Executive Committee, JSC "Naftan", the plant "Polymir", JSC "Gomeltransneft Druzhba", Miory metal rolling mill, the Court of Polotsk and Polotsk region) in the University Council [12].

Comprehensive monitoring of employers ' satisfaction with the quality of professional training at Polotsk State University was first conducted in 2018-2019 within the framework of the international project of the ERASMUS+program "Fostering Competences Development in Belarusian Higher Education (FOSTERC)"[13]. Analysis of employers ' satisfaction with the quality of training of graduates makes it possible to identify the requirements that the employer imposes on the professional training of graduates in various areas of training, to evaluate the competitiveness of the University in the market of educational services through the demand for graduates in the labour market, to determine measures to improve the level of professional competencies of graduates. 
An electronic survey by filling out a questionnaire in Google was used as a research method. The toolkit covered a wide range of issues designed to reveal the educational and work activities of graduates, teaching and learning methods, and much more.

145 organizations participated in the survey of Polotsk State University's employers. The assessment of customer satisfaction with the University's educational services in the framework of this monitoring was carried out on the basis of a competence-based approach. The quality of education as a result of providing educational services is determined by the degree to which a University graduate has formed competencies that allow to apply the acquired knowledge, skills and abilities in solving specific professional tasks; to act in a specific situation, while achieving high results.

The first set of questions for employers was aimed at identifying the evaluation of the level of competencies that graduates have when applying for a job. The second set allowed to identify the necessary level of competencies that a graduate should possess in general. The third set showed an assessment of the degree to which the education received at Belarusian universities is a good basis for graduates to work.

Respondents were asked to rate the proposed 24 competencies on a 5-point scale according to the degree of importance of this competence for them, and then according to the degree of formation. The characteristics of the criteria values are shown in the table [14].

Table 1.

\begin{tabular}{|c|c|}
\hline $1<\mathrm{C} \leq 2,5$ & Dissatisfaction by the criterion \\
\hline $2,5<\mathrm{C} \leq 4,0$ & Middle level of satisfaction by the criterion \\
\hline $4,0<\mathrm{C}<5$ & High level of satisfaction by the criterion \\
\hline
\end{tabular}


Table 2.

\begin{tabular}{|c|c|c|c|}
\hline & $\begin{array}{c}\text { Average merit } \\
\text { of importance, } \\
\text { points }\end{array}$ & $\begin{array}{c}\text { Average merit } \\
\text { of formation, } \\
\text { points }\end{array}$ & Derating \\
\hline Ability to rapidly acquire new knowledge & 4.5 & 4.1 & 0.4 \\
\hline Ability to adapt to changes & 4.5 & 3.9 & 0.6 \\
\hline Ability to perform well under pressure & 4.3 & 3.6 & 0.7 \\
\hline $\begin{array}{l}\text { Ability to comprehend complex problems as a } \\
\text { whole }\end{array}$ & 4.4 & 3.7 & 0.7 \\
\hline Mastery of your own field or discipline & 4.5 & 3.85 & 0.65 \\
\hline $\begin{array}{c}\text { Ability to use information and communication } \\
\text { technology }\end{array}$ & 4.5 & 4.2 & 0.3 \\
\hline Ability to work productively in a team & 4.55 & 4 & 0.55 \\
\hline Analytical thinking & 4.5 & 3.9 & 0.6 \\
\hline Alertness to new opportunities & 4.5 & 4.1 & 0.4 \\
\hline Ability to use time effectively & 4.6 & 3.7 & 0.9 \\
\hline $\begin{array}{c}\text { Ability to plan, organize and coordinate } \\
\text { activities }\end{array}$ & 4.45 & 3.8 & 0.65 \\
\hline $\begin{array}{c}\text { Ability to take decisive action in case of } \\
\text { uncertainty }\end{array}$ & 4.3 & 3.4 & 0.9 \\
\hline $\begin{array}{l}\text { Ability to find new ways and areas to apply } \\
\text { existing knowledges }\end{array}$ & 4.5 & 3.9 & 0.6 \\
\hline $\begin{array}{l}\text { Ability to present products, ideas and reports to } \\
\text { an audience }\end{array}$ & 4.4 & 3.6 & 0.8 \\
\hline Ability to make your meaning clear to others & 4.5 & 3.9 & 0.65 \\
\hline Ability to write reports, memos and documents & 4.4 & 3.7 & 0.7 \\
\hline Ability to negotiate effectively & 4.3 & 3.6 & 0.7 \\
\hline Ability to anticipate a problem & 4.3 & 3.5 & 0.8 \\
\hline Ability to inspire and motivate others & 4.2 & 3.6 & 0.7 \\
\hline Ability to be a team leader & 4.15 & 3.5 & 0.65 \\
\hline $\begin{array}{c}\text { Willingness to question existing and prevailing } \\
\text { ideas }\end{array}$ & 4.15 & 3.7 & 0.45 \\
\hline Knowledge of other fields or disciplines & 4.15 & 3.8 & 0.35 \\
\hline Ability to communicate in a foreign language & 3.9 & 3.2 & 0.7 \\
\hline Ability to come up with new solutions and ideas & 4.5 & 3.9 & 0.6 \\
\hline
\end{tabular}

Thus, employers ' assessments of the level of professional training of working graduates (on a five-point scale) are in the range of the "average" criterion (from 3 to 4 points). This indicates that the content of training programs and the degree of competence development correspond the requirements of employers.

The goal of every student after graduation is to get a decent and well-paid job. If a graduate is not in demand in the labor market, this will immediately affect the position of the University in a particular rating, which will decrease. Questions for graduates can be grouped into 4 main sets. In the first set, graduates evaluated the extent to which learning and teaching methods were used in the process of studying at the University. In the second, they identified the level of competence required in the current work. In the third set, to what extent the study contributed to the development of this competence. The fourth set determined the importance of formed competencies in general.

300 graduates took part in the survey. As a result of the questionnaire analysis, the following results were obtained.

When asked about satisfaction with the training received at the University, $70 \%$ of graduates said that they were fully satisfied with it, $24 \%$ that partially, $4 \%$ found it difficult to answer. Only $1 \%$ are generally dissatisfied. 
When evaluating the level of formation of general professional trainingon a scale of 1 to $5,27.6 \%$ of graduates gave the highest score, $56.2 \%$ rated 4 points, $15.1 \%$ put 3 points. 2 points were given by $0.8 \%$ of respondents.

Assessing the level of formation of practical skills in the course of training, 52.1\% gave 4 points, $21.2 \%$ of respondents rated the highest score, $21 \%$ put 3 points, 2 and 1 point were given by $5 \%$ and $1.7 \%$ of respondents respectively.

In the global economy, the importance of a foreign language as a necessary condition for career growth is increasing. However, the survey showed that despite all the efforts of Polotsk State University (the creation of Centre for foreign languages study, the organization of optional classes, the use of modern teaching methods, the allocation of time in the schedule grid for foreign language classes), the level of foreign language proficiency among graduates remains low. 30.2 and $29.4 \%$ of respondents rated their level of English language proficiency at $\mathrm{A} 2$ and $\mathrm{A} 1$ respectively. 26.9 and $6.4 \%$ on $\mathrm{B} 1$ and $\mathrm{B} 2$ respectively. 2.1 and $4.8 \%$ at $\mathrm{C} 1$ and $\mathrm{C} 2$ levels.

When assessing the level of computer skills and knowledge required when working with software products on a scale from 1 to $5,42.6$ and $46.8 \%$ gave 5 and 4 points, respectively. 1.2 and $9.3 \%$ rated 2 and 3 , respectively.

An important place among the requirements for a modern specialist is occupied by organizational skills, the ability to work in a team. The ability to work in a team was rated at the maximum score by 58.2 per cent of the respondents, 4 points were given by $33.7 \%$ of respondents, 3 points - by $6.1 \%, 2$ - by $1,3 \% 1$ point - by $0,7 \%$.

$36 \%$ of graduates rated their ability to represent themselves and the results of their work at the highest point, $48.9 \%$ gave 4 points, $12.6 \%-3$ points, $2 \%-2$ points, $0.5-1$ point. The same $36 \%$ rated the formation of their management skills by 5 points, $41.5 \%$-by 4 points, $22.6 \%$-by 3 points, $3.8 \%$ - by 2 points, $1.2 \%$ - by 1 point.

$47.6 \%$ of graduates are ready for further training and professional development and see the need for this. $39.8 \%$ rated their readiness formation at 4 points, $11.4 \%$ - at 3 points, $0.7 \%$ - at 2 points, $0.5 \%$ - at 1 point.

$44 \%$ of graduates rated their ability to perceive and analyze new information at 5 points, $44 \%$ - at 4 points, $11.2 \%$ - at 3 points, $0.3 \%$ - at 2 points, and $0.5 \%$-at 1 point.

To the question "If you had to choose a specialty and educational institution, what would you do?" 48\% said that they would choose a specialty at Polotsk State University. $14 \%$ of respondents chose a different specialty, but at Polotsk State University. 3\% chose the same specialty, but not at Polotsk State University. $7 \%$ - another specialty or other educational institution, $25 \%$ - found it difficult to answer.

\section{Conclusion}

Thus, based on the analysis of monitoring the level of satisfaction of external stakeholders, we can draw the following conclusions:

1. the high level of development of such competencies as" Ability to rapidly acquire new knowledge","Alertness to new opportunities", as well as "Ability to use information and communication technology" emphasize the fact that the educational programs of basic and additional education implemented at Polotsk State University provide the knowledge and practical skills necessary for using the latest ICT in professional activities [15].

Monitoring of employers 'satisfaction allowed identifying"problem areas" in the training of a specialist and forming a package of primary recommendations for improving both the management of interaction with partners and the elimination of negative trends [16]. Based on the survey analysis, when designing educational programs, special attention should be paid to the following competencies:

- Ability to take decisive action in case of uncertainty; 
- Ability to adapt to changes

- Ability to use time efficiently

- Ability to present products, ideas or reportsto an audience

2. based on the self-assessment of graduates, during their studies at PolotskSatate University, they have largely formed the competencies necessary for successful work in the modern economy. In the educational experience of graduates, there are enough practices and types of educational activities in which such competencies are formed.

In general, according to graduates of Belarusian universities, the highest level of proficiency is required in the following competencies:

- Ability to rapidly acquire new knowledge

- Ability to adapt to changes

- Ability to perform well under pressure

- Ability to comprehend complex problems as a whole

Mastery of your own field or discipline

According to graduates, studies have contributed least to the development of the following competencies:

- Ability to communicate in a foreign language

- Ability to inspire and motivate others

- Ability to be a team leader

- Ability to negotiate effectively

- Ability to take decisive action in case of uncertainty

The success of graduates of Polotsk State University is a clear evidence of the high quality of training. A distinctive feature of a Polotsk State University's graduate has always been high professionalism and broad outlook, analytical thinking and ability to work in a team. Among the graduates of the University there are impertant state and public figures, successful managers of regional enterprises, in particular N. I.Kochanova, D. V.Demidov, A.M.Niyakovsky, V. N.Filimonov, A. G.Larin, A. N.Khvalko, N. A.Kachanovsky, A. P.Yalovik, V. A.Grishaev, L. V.Petrov, A. L.Shamashov, V. K.Volkov, Yu.N.Chernevich, S. N.Degtyareva, L. V.Sorokina, A.M.Zvonkin, V. V.Morozov, S. M. Kirei [17].

\section{References}

1. V. Savvinov, V. Strekalovsky, Meeting stakeholders' needs through effective university management, International Organisations Research Journal, 87-98, 1 (2013)

2. O. Perfilieva, The university in the region: steps towards third mission, International Organisations Research Journal, 133-144, 1 (2011)

3. I.D. Froumin, M.S Dobryakova, What makes Russian universities change: disengagement compact, Vysshee obrazovanie segodnya [Higher education today], 159-191, 2 (2012)

4. T. K. Ekshikeev, Stakeholders of the educational services market, Sibirskii torgovoekonomicheskii zhurnal [Siberian Trade and Economic Journal], 106-109, 9 (2009)

5. A.P. Klemeshev, E. V. Kudryashova, S.E. Sorokin, Stakeholder approach to the implementation of the 'third mission' of universities, Balt. Reg., 114-135, 4 (2019).

6. E. S. Popova, The mechanism of mutual influence of the directions of regional development and university strategies, Ars Administrandi, 47-54, 2 (2012).

7. K.Yu. Burtseva, The stakeholder approach to the evaluation of universities, Audit and financial analysis, 316-320, 2 (2016) 
8. I.V. Filipova, N.A. Novokreshchenova, O.A. Novokreshchenova, Cooperation with strategic partners: the Russian higher school experience, The Education and Science Journal, 58-74, 3 (2013)

9. D.K. Sabirova, Employers and High Education Institutions: Interaction and Prospects, Upravlenie, 80-85, 2(2014).

10. A.N. Komov, The content and organizational forms of partnership between educational institutions and employers, Economic sciences, 324-327, 4 (2007).

11. M.A. Sergeev, Polotsk state University joined the innovation and industrial petrochemical cluster, Official site of educational institution PSU. https:

//www.psu.by/nauka/novosti-nauki/10786-pguvstupil-v-sostav-innovatsionnopromyshlennogo-neftekhimicheskogoklastera.

12. N.A. Boreiko, Monitoring the satisfaction of the parties: the main results of the stakeholder survey and ways to improve the work of the university in relation to employers. https://fosterc.bsu.by/files/00109/obj/110/12853/doc/ Borejko PGU.pdf

13. About FOSTERC. https://fosterc.bsu.by/o-proekte-fosterc

14. E. B. Dorina, The quality of graduate training through the eyes of employers. https://fosterc.bsu.by/meropriyatiya-proekta/ceminar-«kachestvo-vysshegoobrazovaniya-v-belarusi-glazami-stejkkholderov»/materialy-seminaraA. Barun, N. Dauhiala, D. Dauhiala Staff training in terms of digital economy development: the experience of Polotsk State University (Republic of Belarus), Published by Atlantis Press. This is an open access article under the CC BY-NC license, 258-262. https://doi.org/10.2991/ispcbc-19.2019.64

15. I. A. Matnenko, Monitoring the satisfaction of employers with graduates as a tool for analyzing the requirements for the formation of professional competencies, Siberian Trade and Economic Journal, 60-64, 10 (2010).

16. A. Barun, N. Dauhiala, D. Dauhiala, N. Hryshanava, S. Andryewskaja, Polotsk State University in the Educational Space of Polotsk Region, New Silk Road: Business Cooperation and Prospective of Economic Development, 501-506, (Atlantis Press, 2020). 